\title{
ANALISIS KEMAMPUAN PESERTA DIDIK DALAM MEMECAHKAN MASALAH PADA SOAL CERITA MATERI PERSAMAAN LINIER SATU VARIABEL DITINJAU DARI GAYA BELAJAR DI SMP NU 2 GRESIK
}

\author{
Ma'rifatul Fadilah', Midjan' \\ Universitas Muhammadiyah Gresik ${ }^{1}$ \\ Email: marifah26@gmail.com \\ Universitas Muhammadiyah Gresik ${ }^{2}$ \\ Email : midjanmpd@gmail.com
}

\begin{abstract}
Abstrak
Peserta didik dalam memecahkan soal matematika memiliki cara yang berbedabeda karena setiap individu memiliki kemampuan matematika yang berbeda-beda pula. Masalah-masalah pada soal cerita yang berhubungan dengan matematika sering dijumpai pada situasi sehari-hari. Penyajian matematika dalam bentuk cerita merupakan salah satu fungsi matematika sebagai aktivitas manusia, karena dalam soal cerita terdapat pengalaman-pengalaman peserta didik. Selain dilihat kemampuan dalam memecahkan soal cerita diperhatikan juga aspek perbedaan gaya belajar peserta didik, karena pada proses kegiatan pembelajaran di kelas banyak peserta didik yang terlibat dimana setiap peserta didik memiliki kesempatan yang sama untuk mendapatkan materi dengan sejelas-jelasnya. Perbedan gaya belajar merupakan sebuah pendekatan yang menjelaskan mengenai bagaimana individu belajar atau cara yang ditempuh oleh masing-masing individu untuk berkonsentrasi pada proses, dan menguasai informasi yang sulit dan baru melalui presepsi yang berbeda Grinder mengidentifikasikan 3 jenis gaya belajar, yaitu : gaya belajar visual, auditori, dan kinestetik.

Penelitian ini adalah penelitian deskriptif kualitatif yang bertujuan untuk mendeskripsikan kemampuan peserta didik dalam pemecahan masalah peserta didik SMP NU 2 Gresik kelas VII A pada materi persamaan linier satu variabel ditinjau dari gaya belajar.

Hasil dari penelitian ini adalah kemampuan pemecahan masalah meliputi: Peserta didik visual mengerjakan soal sesuai dengan tahapan polya, saat menghitung menggunakan prosedur tertentu dan jawaban benar. Peserta didik memahami elemen netral (0) tetapi tidak menuliskannya. Peserta didik auditorial mengerjakan soal sesuai dengan tahapan polya, tetapi setelah peserta didik melakukan tahap memeriksa kembali pemecahan justru membuat peserta didik ragu dalam memberikan kesimpulan akhir. Peserta didik kinestetik saat mengerjakan soal terkadang melewatkan beberapa proses tahapan Polya. Karena peserta didik lebih suka menggunakan cara praktis dan mengabaikan persamaan matematikanya. Persamaan matematika tidak bermakna bagi peserta didik kinestetik.
\end{abstract}

Kata Kunci: Pemecahan Masalah, Soal Cerita, Gaya Belajar Visual, Gaya Belajar Auditori, Gaya Belajar Kinestetik

\footnotetext{
Abstract

Learners in solving math problems have different ways because each individual has different math skills as well. Problems with mathematics-related problems are often encountered in everyday situations. The presentation of mathematics in the form of a story is one of the functions of mathematics as a human activity, because in the matter of
} 
stories there are experiences of learners. In addition to seeing the ability to solve the problem of the story is also considered the different aspects of learning styles of learners, because in the process of learning activities in the class many learners are involved where each learner has the same opportunity to get the material as clearly as possible. Learning style difference is an approach that explains how individuals learn or how each individual takes to concentrate on the process, and mastering the difficult and new information through different perceptions Grinder identifies three types of learning styles: visual learning styles, auditory, and kinesthetic.

This research is a qualitative descriptive research that aims to describe the ability of learners in solving the problem of students of SMP NU 2 Gresik class VII A on the material of linear equations of one variable in terms of learning style.

The result of this research is problem solving ability include: Visual learners do the questions in accordance with the stage polya, when calculating using certain procedures and correct answers. Learners understand the neutral element (0) but do not write it down. Auditorial learner work on the problem in accordance with the stages polya, but after the learners do re-examine the solution makes the students hesitant in giving the final conclusion. Kinesthetic learners while working on problems sometimes skip some of the Polya stage processes. Because learners prefer to use practical means and ignore mathematical equations. Mathematical equations are not meaningful for kinesthetic learners.

Keywords: Problem Solving, Story Problem, Visual Learning Style, Auditory Learning Style, Kinesthetic Learning Style

\section{PENDAHULUAN}

Pembelajaran matematika yang diberikan mulai dari sekolah dasar hingga ditingkat selanjutnya, memberikan peran penting bagi peserta didik dalam mengembangkan kemampuan dan memiliki peranan strategis dalam upaya peningkatan Sumber Daya Manusia (SDM). Secara umum, manfaat pembelajaran matematika pada jenjang Sekolah Menengah Pertama (SMP) menurut Kurikulum 2013 adalah cara berpikir matematika itu sistematis, melalui urutan-urutan yang teratur dan tertentu. dengan belajar matematika, otak kita terbiasa untuk memecahkan masalah secara sistematis (Kemendikbud, 2014). Sehingga bila diterapkan dalam kehidupan nyata, kita bisa menyelesaikan setiap masalah dengan lebih mudah. Dari manfaat matematika tersebut peserta didik harus mampu untuk memecahkan masalah dalam pembelajaran matematika terutama pada memecahkan masalah soal cerita. Soal cerita matematika merupakan soal matematika yang dinyatakan dalam persoalanpersoalan yang terkait dengan permasalahan-permasalahan dalam kehidupan sehari-hari yang dapat 
dicari penyelesaiannya dengan menggunakan kalimat matematika (Raharjo dan Astuti, 2011: 8). Soal cerita seringkali muncul dalam ujian, baik dalam ulangan harian, Ujian Tengah Semester (UTS), Ujian Akhir Semester (UAS), dan Ujian Nasional. Soal cerita juga mempunyai peranan penting dalam pembelajaran matematika karena soal cerita sangat bermanfaat untuk perkembangan proses berfikir karena dalam memecahkan masalah yang ada dalam soal cerita memerlukan langkah-langkah penyelesaian yang membutuhkan pemahaman dan penalaran. Tetapi masih banyak peserta didik yang mengalami kesulitan dalam mengerjakan soal cerita karena peserta didik mengalami kesulitan dalam menerjemahkan kalimat-kalimat pada soal untuk diubah ke dalam bentuk matematika, hal tersebut berdasarkan hasil wawancara peneliti dengan guru matematika di SMP NU 2 Gresik.

\section{METODE PENELITIAN}

\section{Jenis penelitian}

Jenis penelitian yang digunakan merupakan penelitian deskriptif kualitatif. Menurut Best
(Sukardi, 2008: 157) penelitian deskriptif merupakan metode penelitian yang berusaha menggambarkan dan menginterpretasikan objek sesuai dengan apa adanya. Dan menurut Moleong (2013:6) penelitian kualitatif adalah suatu penelitian yang bertujuan untuk memahami halhal yang dialami oleh subjek penelitian misalnya perilaku, persepsi, motivasi, tindakan dan lainlain, secara deskriptif dalam bentuk kata-kata dan bahasa, pada suatu konteks khusus yang alamiah dan dengan memanfaatkan berbagai metode ilmiah. Penelitian deskriptif kualitatif bertujuan untuk mendeskripsikan kemampuan peserta didik dalam memecahkan masalah soal cerita ditinjau dari gaya belajar.

\section{Lokasi Penelitian dan Waktu Penelitian}

Penelitian ini dilaksanakan di SMP NU 2 Gresik yang beralamatkan di Jalan Raden Santri, Gresik. penelitian dilaksanakan pada semester ganjil tahun ajaran 2017/2018.

\section{Subjek Penelitian}

Subjek dalam penelitian ini adalah peserta didik kelas VII A SMP NU 2 Gresik. Dipilihnya kelas 
VII A karena lebih aktif pada saat pembelajaran matematika. Kelas VII A terdiri dari 20 peserta didik, pemilihan subjek penelitian menggunakan purposive sampling yaitu teknik yang dilakukan dengan menentukan siapa yang termasuk anggota sampel penelitiannya dan peneliti harus benar-benar mengetahui bahwa responden yang dipilih dapat memberikan informasi yang diinginkan sesuai dengan permasalahan peneliti (Sugiyono, 2013).

\section{Metode Pengumpulan Data}

\section{Metode Tes}

Metode tes adalah serentetan pertanyaan atau latihan serta alat lain yang digunakan untuk mengukur keterampilan, pengetahuan, intelegensi, kemampuan atau bakat yang dimiliki individu atau kelompok (Arikunto, 2013: 193).

\section{Metode Wawancara}

Metode wawancara adalah sebuah dialog yang dilakukan oleh pewawancara untuk memperoleh informasi dari terwawancara (Arikunto, 2013: 198). Metode wawancara digunakan untuk mendapatkan data langsung tentang kemampuan memecahkan masalah matemateka peserta didik berdasarkan pemecahan polya ditinjau dari gaya belajar.

\section{Instrumen Penelitian}

Instrumen Tes

a. Tes Gaya Belajar

Tes penilaian terhadap hasil tes gaya belajar peserta didik diberikan sebelum proses pembelajaran karena peneliti ingin mengetahui setiap jenis gaya belajar dari peserta didik. Dimana, soal terdiri dari 36 butir soal yang masing-masing 12 butir soal jenis gaya belajar visual, 12 butir soal jenis gaya belajar auditorial, dan 12 butir soal jenis gaya belajar kinestetik.

b. Tes Pemecahan Masalah Matematika

Untuk mendapatkan data kemampuan pemecahan masalah matematika, instrumen yang digunakan adalah lembar tes pemecahan masalah matematika dengan menggunakan soal cerita. Tes yang digunakan dalam penelitian ini adalah tes tertulis yang disusun berdasarkan indikator-indikator pemecahan masalah berdasarkan langkah-langkah polya yang harus diselesaikan secara individu. Adapun soal tes 
tersebut terdiri dari lima soal tes yang sebelumnya dikonsultasikan terlebih dahulu kepada pembimbing dan guru matematika SMP NU 2 Gresik yang menentukan soal-soal layak atau tidak digunakan dan diuji mengguakan reliabilitas dan validitas.

\section{Pedoman Wawancara}

Pedoman wawancara berisi pertanyaan yang diajukan kepada peserta didik untuk mengetahui lebih lanjut kemampuan peserta didik dalam memecahkan masalah sesui dengan gaya belajar masing-masing peserta didik.

\section{Teknik Analisis Data}

\section{Analisis data gaya belajar}

Untuk mengetahui jenis gaya belajar peserta didik maka akan hasil tes digunakan dengan perhitungan berikut: a. Menilai jawaban peserta didik dengan skoring

\section{Tabel 3.1 Pedoman Penskoran} Tes Gaya Belajar

\begin{tabular}{|c|c|}
\hline Keterangan & Skor \\
\hline Sering & 2 \\
\hline $\begin{array}{c}\text { Kadang- } \\
\text { kadang }\end{array}$ & 1 \\
\hline Jarang & 0 \\
\hline
\end{tabular}

(DePotter, 2014: 214)

b. Menjumlahkan hasil penilaian pada setiap bagian

c. Mengkategorikan peserta didik termasuk dalam jenis gaya belajar visual, auditorial, atau kinestetik.

\section{Analisis Data Tes Pemecahan}

Masalah

Adapun lembar penilaian kemampuan pemecahan masalah matematika peserta didik adalah sebagai berikut:

Tabel 3.2 Pedoman Penskoran Tes Pemecahan Masalah

\begin{tabular}{|c|c|c|}
\hline Aspek yang dinilai & Reaksi terhadap soal (masalah) & Skor \\
\hline \multirow[t]{4}{*}{$\begin{array}{l}\text { Memahami } \\
\text { masalah }\end{array}$} & $\begin{array}{l}\text { Tidak menuliskan apa yang diketahui dan apa } \\
\text { yang ditanyakan dari soal }\end{array}$ & 1 \\
\hline & Hanya menuliskan apa yang diketahui & 2 \\
\hline & $\begin{array}{l}\text { Menuliskan apa yang diketahui dan apa yang } \\
\text { ditanyakan dari soal dengan kurang tepat }\end{array}$ & 3 \\
\hline & $\begin{array}{l}\text { Menuliskan apa yang diketahui dan apa yang } \\
\text { ditanyakan dari soal dengan tepat }\end{array}$ & 4 \\
\hline
\end{tabular}




\begin{tabular}{|c|c|c|}
\hline \multirow{4}{*}{$\begin{array}{c}\text { Merencanakan } \\
\text { pemecahan }\end{array}$} & Tidak menyajikan urutan langkah penyelesaian & 1 \\
\hline & $\begin{array}{l}\text { Menyajikan urutan langkah penyelesaian, tetapi } \\
\text { urutan-urutan penyelesaian yang disajikan } \\
\text { kurang tepat }\end{array}$ & 2 \\
\hline & $\begin{array}{l}\text { Menyajikan urutan langkah penyelesaian yang } \\
\text { benar, tetapi mengarah pada jawaban yang salah }\end{array}$ & 3 \\
\hline & $\begin{array}{l}\text { Menyajikan urutan langkah penyelesaian yang } \\
\text { benar dan mengarah pada jawaban yang benar }\end{array}$ & 4 \\
\hline \multirow{4}{*}{$\begin{array}{l}\text { Melakukan } \\
\text { rencana } \\
\text { pemecahan }\end{array}$} & Tidak ada penyelesaian sama sekali & $\mathbf{1}$ \\
\hline & Ada penyelesaian tetapi prosedur tidak jelas & 2 \\
\hline & $\begin{array}{l}\text { Menggunakan prosedur tertentu yang benar } \\
\text { tetapi jawaban salah }\end{array}$ & 3 \\
\hline & $\begin{array}{l}\text { Menggunakan prosedur tertentu yang benar dan } \\
\text { hasil benar }\end{array}$ & 4 \\
\hline \multirow{4}{*}{$\begin{array}{l}\text { Memeriksa } \\
\text { kembali } \\
\text { pemecahan }\end{array}$} & $\begin{array}{l}\text { Tidak melakukan pengecekan terhadap proses } \\
\text { dan jawaban serta tidak memberikan kesimpulan }\end{array}$ & 1 \\
\hline & $\begin{array}{l}\text { Tidak melakukan pengecekan terhadap proses } \\
\text { dan jawaban dan memberikan kesimpulan yang } \\
\text { salah }\end{array}$ & 2 \\
\hline & $\begin{array}{l}\text { Melakukan pengecekan terhadap proses dan } \\
\text { jawaban dengan kurang tepat serta memberikan } \\
\text { kesimpulan yang benar }\end{array}$ & 3 \\
\hline & $\begin{array}{l}\text { Melakukan pengecekan terhadap proses dan } \\
\text { jawaban dengan tepat serta membuatkesimpulan } \\
\text { dengan benar }\end{array}$ & 4 \\
\hline
\end{tabular}

Sumber: Suci(2012):

Nilai akhir $=$ $\times 100$

\section{Analisis Data Hasil Wawancara}

Setelah subjek penelitian selesai, kemudian dilakukan wawancara, dan peneliti mendapatkan hasil wawancara kemudian dianalisis untuk mendapatkan informasi 
tambahan dengan cara sebagai berikut:

1. Merduksi data, yaitu proses penyederhanaan yang dilakukan melalui seleksi, pemfokusan, dan pengabstraksian data mentah menjadi data yang bermakna. Hal tersebut dapat dilakukan dengan cara sebagai berikut:

(1) Membaca kembali catatan dan informasi yang didapat pada saat kegiatan penelitian.

(2) Mentranskripsi hasil wawancara yang berupa perkataan dari subjek penelitian termasuk mimik dan ekspresi subjek saat wawancara berlangsung.

(3) Menyederhanakan data/informasi yang diperoleh dari hasil tes subjek penelitian dan hasil wawancara.

(4) Mengidentifikasi gaya belajar yang dimiliki oleh subjek penelitian berdasarkan hasil tes gaya belajar dan hasil wawancara.

2. Pemaparan data yang diperoleh dari hasil wawancara meliputi kegiatan mengklarifikasi dan mengidentifikasi data. Pemaparan data dalam penelitian ini adalah membahas data hasil wawancara yang valid sebagai informasi tambahan untuk mendeskripsikan kemampuan peserta didik dalam memecahkan masalah pada soal cerita materi persamaan linier satu variabel ditinjau dari gaya belajar.

\section{PROSEDUR PENELITIAN}

Prosedur penelitian ini dibagi dalam tiga tahap sebagai berikut:

\section{Tahap Persiapan}

Sebelum melakukan penelitian, maka hal-hal yang perlu dilakukan adalah sebagai berikut:

a. Berkonsultasi dengan dosen pembimbing tentang proposal penelitian.

b. Meminta surat ijin penelitian dari Universitas Muhammadiyah Gresik.

c. Meminta ijin kepada kepala sekolah untuk melakukan penelitian.

d. Berkonsultasi dengan guru bidang studi matematika di SMP NU 2 Gresik untuk menentukan waktu penelitian.

e. Membuat Angket Gaya Belajar

f. Menyusun soal tes pemecahan masalah yang 
sebelumnya didiskusikan dengan dosen pembimbing dan guru matematika SMP NU 2 Gesik

g. Melakukan validasi soal

\section{Tahap Pelaksanaan}

a. Pemberian tes Gaya belajar Pemberian tes gaya belajar kepada kelas VII A, kemudian menghitung skor dari masingmasing peserta didik. Hasilnya akan digunakan untuk mengelompokan kategori gaya belajar peserta didik yaitu gaya belajar visual, auditorial, dan kinestetik.

b. Pemberian tes pemecahan masalah matematika

Tes pemecahan masalah matematika merupakan tes yang diberikan kepada peserta didik setelah melaksanakan tes gaya belajar. Tes ini diberikan pada seluruh peserta didik kelas VII A Hasil tes ini digunakn untuk mengetahui kemampuan pemecahan malah matematika peserta didik.

c. Wawancara subjek penelitian Wawancara peserta didik dilakukan kepada subjek penelitian secara bergantian. Masing-masing subjek menjawab pertanyaan yang diberikan berdasarkan pedoman wawancara yang telah dibuat peneliti. Keenam subjek wawancara untuk mengonfirmasi jawaban subjek atas soal tes yang telah diberikan untuk mengecek keabsahan data penelitian

\section{Tahap Analisis Data}

Pada tahap ini, peneliti menganalisis data setelah data terkumpul dengan menggunakan Triangulasi, triangulasi diartikan sebagai teknik pengumpulan data yang bersifat menggabungkan dari berbagai teknik pengumpulan data dan sumber yang telah ada (Sugiyono, 2013: 83). Pada penelitian ini peneliti menggunakan triangulasi teknik, berarti peneliti menggunakan teknik pengumpulan data yang berbeda-beda untuk mendapatkan data dari sumber yang sama. Dimana data tes gaya belajar, data tes pemecahan masalah, dan hasil wawancara dicocokan sehingga mendapat data yang valid. Selanjutnya peneliti membuat laporan yang mendeskripsikan tentang kemampuan peserta didik dalam memecahkan masalah pada soal cerita materi persamaan linear satu variabel ditinjau dari gaya 
belajar. Untuk lebih jelasnya peneliti pada gambar berikut.

menyajilakn dalam bentuk diagram

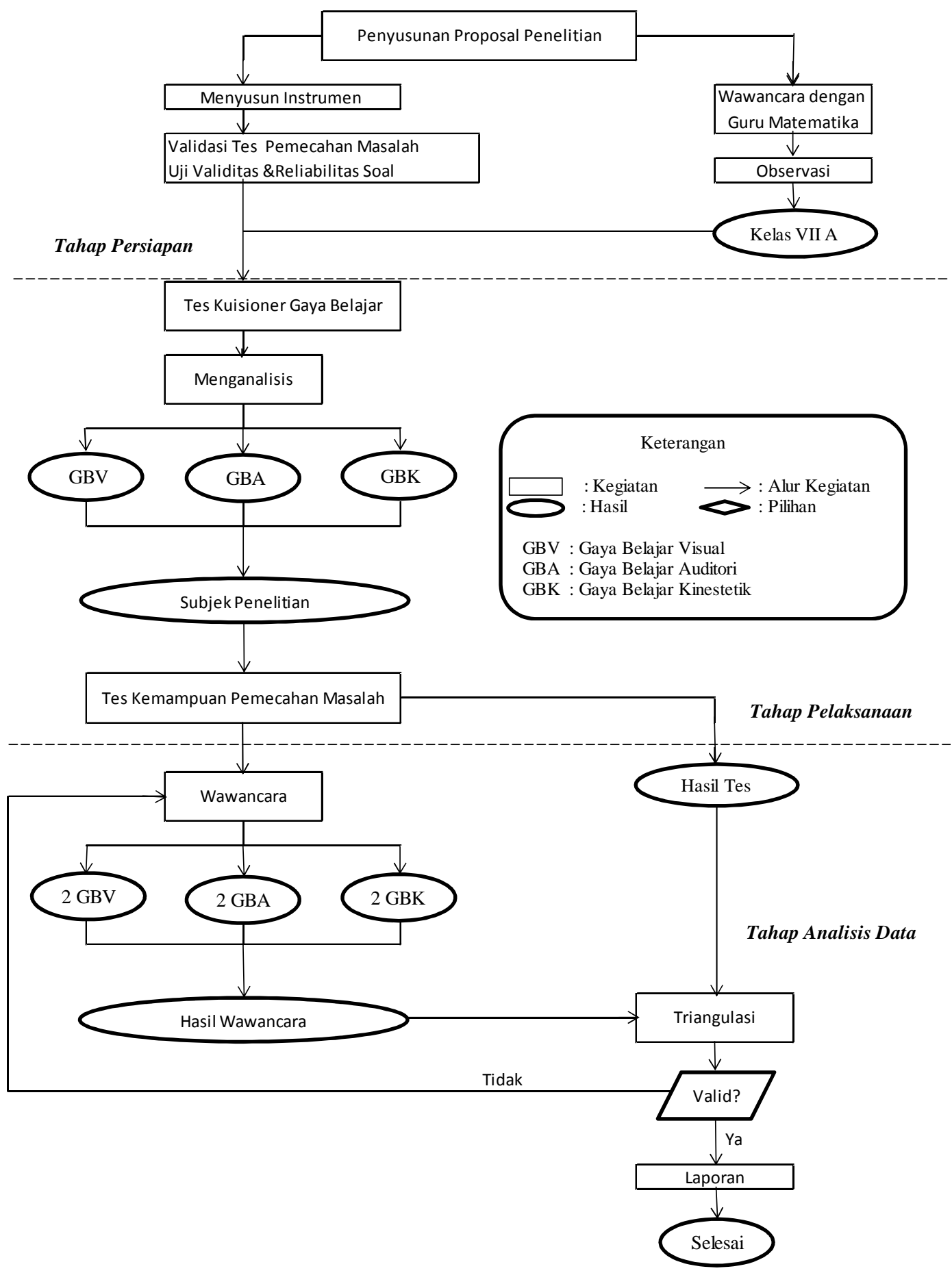


HASIL DAN ANALISIS DATA

\section{Tes Gaya Belajar}

Pada penelitian ini, peneliti menggunakan angket gaya belajar yang diambil dari buku Quantum Teaching yang terdiri dari 32 butir yaitu soal 12 butir soal visual, 12 butir soal Aditorial, dan 12 butir soal Kinestetik. Peneliti melakukan tes gaya belajar pada tanggal 09 November 2017 yang diikuti oleh 20 peserta didik. dapat dilihat secara umum pada tabel berikut:

Tabel 4.4 Hasil Tes Gaya Belajar Peserta Didik

\begin{tabular}{|l|l|l|l|l|l|l|}
\hline No & $\begin{array}{l}\text { No } \\
\text { Induk }\end{array}$ & Visual & Auditorial & Kinestetik & Keterangan & $\begin{array}{l}\text { Subyek } \\
\text { penelitian }\end{array}$ \\
\hline 1 & 4685 & 8 & 18 & 16 & Auditorial & GBA01 \\
\hline 2 & 4686 & 15 & 8 & 9 & Visual & GBV01 \\
\hline 3 & 4689 & 14 & 12 & 16 & Kinestetik & GBK01 \\
\hline 4 & 4692 & 14 & 10 & 4 & Visual & GBV02 \\
\hline 5 & 4694 & 13 & 18 & 11 & Auditorial & GBA02 \\
\hline 6 & 4696 & 11 & 13 & 17 & Kinestetik & GBK02 \\
\hline
\end{tabular}

Pada tahap ini peneliti hanya Pada penelitian ini, peneliti memilih 2 peserta didik dari masingmasing gaya belajar, mengapa peneliti hanya memilih 2 peserta didik yaitu dengan alasan agar pada tahap analisis lebih memahami kemampuan peserta didik dalam memecahkan masalah. Pemilihan subjek yaitu sesuai dengan skor tertinggi di bandingkan dari gaya belajar lainnya. Sehingga terdapat 6 peserta didik dalam subjek penelitian ini. menggunakan 5 soal berbentuk soal cerita, dan peserta didik dianjurkan menggunakan tahap pemecahan polya yaitu (1) memahami masalah, (2) merencanakan pemecahan, (3) melakukan rencana pemecahan (4) memeriksa kembali pemecahan. Peneliti melakukan tes pemecahan masalah pada rabu, 15 November 2017 yang diikuti oleh 20 peserta didik. Hasil tes pemecahan masalah lebih lengkapnya dapat dilihat secara Tes Pemecahan Masalah umum pada tabel berikut:

Tabel 4.5 Hasil Tes Pemecahan Masalah Subjek Penelitian

\begin{tabular}{|l|c|c|c|l|}
\hline No & No Induk & Nilai & $\begin{array}{c}\text { Jenis Gaya } \\
\text { Belajar }\end{array}$ & Kode \\
\hline 1 & 4686 & 93,75 & Visual & GBV01 \\
\hline 2 & 4692 & 95 & Visual & GBV02 \\
\hline 3 & 4685 & 96,25 & Auditorial & GBA01 \\
\hline 4 & 4694 & 95 & Auditorial & GBA02 \\
\hline
\end{tabular}




\begin{tabular}{|l|c|c|c|c|}
\hline 5 & 4689 & 62,5 & Kinestetik & GBK01 \\
\hline 6 & 4696 & 80 & Kinestetik & GBK02 \\
\hline
\end{tabular}

1. Analisis Kemampuan Peserta Didik Gaya Belajar Visual (GBV01) berdasarkan tahapan Polya Pada tahap 3 (melakukan rencana pemecahan) peserta didik menggunakan prosedur tertentu dan jawaban benar. Peserta didik memahami elemen netral (0) tetapi tidak menuliskannya

2. Analisis Kemampuan Peserta Didik Gaya Belajar Visual (GBV02) berdasarkan tahapan Polya

Di nomor 4 peserta didik kurang teliti saat membaca soal dan menuliskan persamaan yang salah sehingga berakibat pada hasil akhir.

3. Analisis Kemampuan Peserta Didik Gaya Belajar Auditorial (GBA01) berdasarkan tahapan Polya. Peserta didik kurang teliti saat mengerjakan soal nomor 5, pada tahap 2 (merencanakan pemecahan) langkah penyelesaiannya sudah benar, tetapi di tahap 3 (melakukan rencana pemecahan) angkanya berubah dan mendapatkan hasil yang salah, dibeberapa soal tidak menarik kesimpulan karena peserta didik ragu saat akan menarik kesimpulan.

4. Analisis Kemampuan Peserta Didik Gaya Belajar Auditorial (GBA02) berdasarkan tahapan Polya. Pada tahap memeriksa kembali justru membuat peserta didik ragu-ragu dalam memberi kesimpulan akhir.

5. Analisis Kemampuan Peserta Didik Gaya Belajar Kinestetik (GBK01) berdasarkan tahapan Polya. Peserta didik tidak melakukan pemecahan masalah sesuai dengan prosedur polya, karena peserta didik lebih menyuukai cara praktis

6. Analisis Kemampuan Peserta Didik Gaya Belajar Kinestetik (GBK02) berdasarkan tahapan Polya. Peserta didik memahami permasalahan yang ada pada soal tetapi peserta didik menggunakan cara praktis dan mengabaikan persamaan matematikanya, sehingga terkadang salah saat mengerjakan soal. 


\section{Pembahasan}

Berdasarkan analisis peserta didik saat mengerjakan soal tes pemecahan masalah, gaya belajar visual saat mengerjakan tes pemecahan masalah melakukan setiap proses tahapan pemecahan masalah Polya. Saat mengerjakan soal pemecahan masalah peserta didik mengerjakan dengan tenang tanpa banyak bertanya kepada guru maupun temannya. Gaya belajar auditorial saat mengerjakan tes pemecahan masalah peserta didik melakukan setiap tahapan pemecahan masalah Polya tetapi peserta didik tidak bisa tenang saat mengerjakan soal, seringkali peserta didik bertanya pada guru maupun pada temannya. Gaya belajar kinestetik saat mengerjakan tespemecahan masalah, peserta didik mengerjakan dengan tenang tetapi sering kali tidak menggunakan prosedur Polya, peserta didik terburu-buru saat mengerjakannya.

Berdasarkan analisis peserta didik saat dilakukan tes wawancara, peserta didik visual membaca soal tanpa meneluarkan suara dan menuliskan beberapa rencana sebelum menjawab pertanyaan yang diajukan oleh peneliti . Peserta didik auditorial membaca soal dengan mengeluarkan suara pelan dan terkadang hanya menggerakan bibirnya dan seringkali peserta didik ragu-ragu saat menarik kesimpulan. Peserta didik kinestetik membaca soal tanpa bersuara tapi sambil menggerak-gerakan kakinya terkadang menggunakan pena untuk menunjuk soal yang sedang dibaca.

\section{KESIMPULAN}

Berdasarkan hasil dan analisis pada bab IV, peneliti menyimpulkan kemampuan memecahkan masalah berdasarkan tahapan Polya pada peserta didik SMP NU 2 Gresik kelas VII A materi persamaan linier satu variabel ditinjau dari gaya belajar terhadap 6 subjek penelitian, dapat disimpulkan sebagai berikut:

1. Peserta didik visual mengerjakan soal sesuai dengan tahapan polya, saat menghitung menggunakan prosedur tertentu dan jawaban benar. Peserta didik memahami elemen netral (0) tetapi tidak menuliskannya 2. Peserta didik auditorial mengerjakan soal sesuai dengan tahapan polya, tetapi setelah peserta didik melakukan tahap memeriksa kembali pemecahan justru membuat 
peserta didik ragu dalam

Berkelompok".

Ejournal

memberikan kesimpulan akhir.

Unesa, 1 (2).

3. Peserta didik kinestetik saat mengerjakan soal terkadang melewatkan beberapa proses tahapan Polya. Karena peserta didik lebih suka menggunakan cara praktis dan mengabaikan persamaan matematikanya. Persamaan matematika tidak bermakna bagi peserta didik kinestetik.

\section{DAFTAR PUSTAKA}

De Porter, Bobbi dkk. 2014. Quantum Teaching:

Mempraktikan Quantum Learning di Ruang Kelas. Penterjemah Ary Nilandari. Bandung: Kaifa

Kemendikbud. 2014.

Permendikbud No. 58 tentang Kurikulum SMP/MTs. Jakarta: Kementrian dan Kebudayaan.

Moleong, Lexy J. 2013. Metode Penelitian Kualitatif. Edisi Revisi. Bandung : PT. Remaja Rosdakarya

Rahardjo, Marsudi dan Astuti Waluyati. 2011. Pembelajaran Soal Cerita Operasi Hitung Campuran Di Sekolah Dasar. Jakarta: Rineka Cipta.

Sugiyono. 2013. Memahami Penelitian Kualitatif. Bandung: ALFABETA.

Sukardi. 2007. Matodologi Penelitian Pendidikan. Jakarta: PT. Bumi Aksara.

Suci, A. A. W dan Rosyidi, A. H. 2012. "Kemampuan Pemecahan Masalah Matematika Siswa Pada Pembelajaran Problem Posing 